\title{
Adapting the social-ecological system framework for urban stormwater management: the case of green infrastructure adoption
}

\author{
Carli D. Flynn ${ }^{1}$ and Cliff I. Davidson ${ }^{1,2}$
}

\begin{abstract}
Stormwater management has long been a critical societal and environmental challenge for communities. An increasing number of municipalities are turning to novel approaches such as green infrastructure to develop more sustainable stormwater management systems. However, there is a need to better understand the technological decision-making processes that lead to specific outcomes within urban stormwater governance systems. We used the social-ecological system (SES) framework to build a classification system for identifying significant variables that influence urban stormwater governance decisions related to green infrastructure adoption. To adapt the framework, we relied on findings from observations at national stormwater meetings in combination with a systematic literature review on influential factors related to green infrastructure adoption. We discuss our revisions to the framework that helped us understand the decision by municipal governments to adopt green infrastructure. Remaining research needs and challenges are discussed regarding the development of an urban stormwater SES framework as a classification tool for knowledge accumulation and synthesis.
\end{abstract}

Key Words: green infrastructure; social-ecological systems framework; stormwater management; technology adoption

\section{INTRODUCTION}

The lack of well-integrated urban stormwater management strategies throughout the past century has left a heritage of environmental and social problems that policy-makers continue to deal with today. Municipal stormwater management plans in many developed countries have favored the use of gray infrastructure (e.g., sewer separation projects, deep storage tunnels, and regional treatment facilities). These engineering solutions can be costly, tend to promote centralized subsurface conveyance systems with end-of-pipe treatment, and often take years to complete. Despite major investments in stormwater infrastructure, urban areas continue to experience critical problems in managing water flows, including flooding, surface water impairment, and combined sewer overflows (USEPA 2004, National Research Council 2009, Coles et al. 2012).

Recent advances in stormwater management methods seek to enhance the sustainability of urban water systems. For instance, stormwater systems that include green infrastructure (GI), also known as low impact development, are recognized as a more sustainable approach. GI technologies are designed to protect or restore the natural hydrology of a site, capturing stormwater volume through the use of engineered systems that mimic natural hydrologic systems. Comprehensive GI programs can be implemented for a variety of outcomes, including flood control, surface water quality improvement, and water harvesting, in conjunction with a broad range of additional outcomes such as ecosystem restoration, air quality improvement, and urban heat reduction (Hatt et al. 2004, Villarreal et al. 2004, Walsh et al. 2005, Tzoulas et al. 2007). However, there are potential practical limitations for GI to achieve sustainable outcomes for municipalities, such as a limited capacity for storing and infiltrating stormwater.

The decision to adopt a comprehensive GI program is influenced by a complex array of social and biophysical factors. To explore such complexities, an urban water system can be understood as a social-ecological system (SES), or a collection of dynamic systems that coevolve through interactions among actors, institutions, and water systems, such as source water, groundwater, wastewater, and stormwater (Berkes et al. 1998, Holling and Gunderson 2002). The stormwater flows and storage volumes within an urban water SES represent common-pool resources, in that water quality and available storage volumes are diminished as runoff flows through urban environments. These issues prompt the need for public authorities to establish various standards related to the management of stormwater.

A fundamental component of urban stormwater SESs is the role of technology as a critical interface between the social and ecological structures, which allows actors to shape different processes to achieve outcomes in system functioning (Ferguson et al. 2013). Technologies also act as a feedback mechanism between the social and biophysical systems of an SES. Walker et al. (2004) describe the potential of an SES intervention to create a new system when the conditions of an existing system are weakened. Stormwater management systems that are exclusively composed of gray infrastructure may result in urban water system weakening because these technology systems are considered neither sustainable nor sufficiently resilient to accommodate climatic changes, and may result in unforeseen outcomes such as high economic costs and environmental justice issues (Pahl-Wostl 2007, Novotny et al. 2010, Dominguez et al. 2011, Pyke et al. 2011, Wendel et al. 2011, De Sousa et al. 2012). Alternatively, extensive use of GI in stormwater management represents an opportunity for transformational shifts in urban water SESs away from point source solutions to decentralized, systematic techniques that may also bring multiple benefits to communities (Shuster and Garmestani 2015).

There is a need to more easily relate attributes and configurations of urban stormwater SESs to particular outcomes, such as the development of comprehensive GI programs. Several frameworks exist which conceptualize and operationalize SES dynamics, each of which may provide different types of diagnostic insights. Thus, an analyst must be clear about the aim and purpose of any 
diagnostic procedure, and hence, which analytic framework will support the specific procedure being undertaken (Ferguson et al. 2013). Binder et al. (2013) provide an overview of the prevailing frameworks for analyzing SESs, and provide guidance on the selection of an appropriate framework. Scholars studying water systems have developed frameworks that identify key processes and structures affecting their governance (Pahl-Wostl et al. 2010, Wiek and Larson 2012). Because GI represents a suite of innovative technologies for many urban water SESs, it is necessary to first identify and define attributes that may prove to be significant in social-ecological interactions before establishing causal mechanisms linking conditions and governance outcomes. Providing a framework to organize and document SES attributes can serve this function.

Our primary goal is to identify the influential SES attributes related to the development of municipal urban stormwater programs that feature GI. We chose the SES framework because it provides a systematic and comprehensive method for defining system attributes and identifying those that are associated with outcomes of interest (Ostrom 2007, 2009). Numerous environmental case studies have applied the SES framework while adding or redefining attributes to best characterize the SES of interest (Fleischman et al. 2010, Gutiérrez et al. 2011, Cinner et al. 2012, Basurto et al. 2013, Nagendra and Ostrom 2014, Marshall 2015, Partelow and Boda 2015). No such effort has been previously undertaken to assess the suitability of the SES framework to characterize urban stormwater management systems. We use qualitative methods to identify and define the attributes most commonly associated with the inclusion of GI in municipal urban stormwater programs.

\section{METHODS}

The identification of attributes associated with GI adoption in municipal urban stormwater programs included several phases of data collection and analysis (Fig. 1). Exploratory work began with observations at GI summits in 2013 and 2014, in which delegates from U.S. municipalities were invited to discuss their respective community's GI programs. Extensive field notes from both meetings were coded line-by-line to identify factors that affected decisions to adopt municipal GI programs. The resulting codes were grouped into general categories of attributes that emerged during the analysis process. These categories were then incorporated into the SES framework, using first- and secondtier modifications, as suggested by McGinnis and Ostrom (2014), Epstein et al. (2013), and Vogt et al. (2015), as the initial framework.

Another stage of data collection included a literature review of original research efforts related to the adoption and implementation of GI in urban stormwater systems. Green infrastructure, green stormwater infrastructure (GSI), low impact design (LID), and best management practices (BMPs) are among the terms used for various suites of urban stormwater management technologies. We refer to GI, GSI, and LID technologies are "GI" because these terms are often used synonymously (Fletcher et al. 2014). Searches were carried out using Scopus, Web of Knowledge, and Google Scholar. Key words included in the literature review were "green infrastructure," "low impact development," "stormwater," and "municipal." Searches were conducted for studies published between 2000 and 2015. In total, 135 articles, theses, and reports were reviewed for their

relevance to factors affecting the adoption and implementation of GI technologies for municipal programs. Reasons for exclusion included a study focus on adoption of water systems other than stormwater (e.g., drinking water, wastewater), or an exclusive focus on GI technology design attributes outside the context of municipal stormwater management program implementation (e.g., experimental findings). Studies were not excluded on the basis of study design, the scale or primary design goal of stormwater technologies discussed, nor the geographical location of the study; however, most studies reviewed were based in the United States or Australia. This process resulted in 83 studies that met the criteria, and thus formed the basis of the review.

Fig. 1. Sequence of data collection and analysis. (SESF: socialecological system framework)

\section{Data Collection}

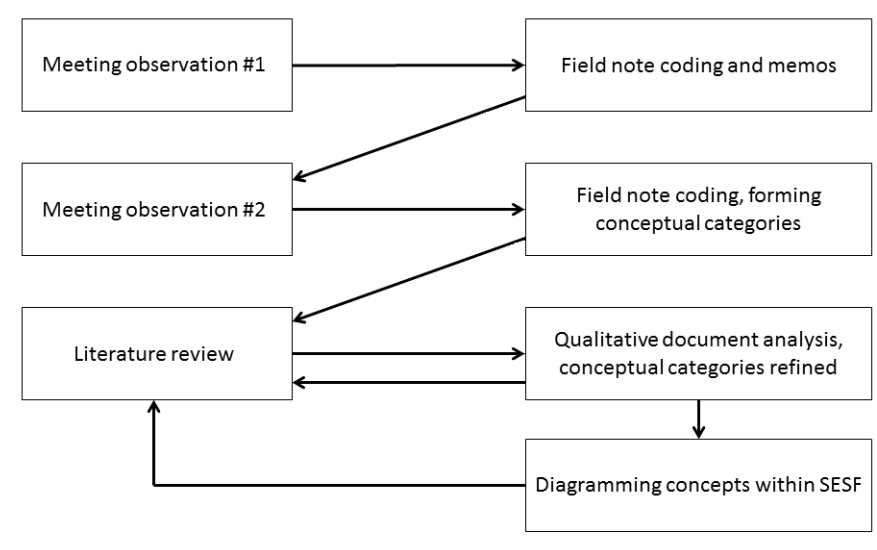

Qualitative document analysis techniques were used to identify factors that influence municipal GI programs in each of the collected studies. These methods often involve the development of a "protocol," which is tested on each unit of analysis and revised based on the quality and likely efficiency of the results (Altheide et al. 2008). The SES framework adapted in the initial research phase served as a beginning protocol that consisted of identified attributes related to GI adoption. After analyzing each study of the literature review, new findings were organized within the protocol. After all studies were analyzed, each study was reviewed a second time to test the protocol. This process resulted in the addition or redefining of second-tier SES framework attributes and the development of new third-, fourth-, and fifth-tier attributes presented in Table 1. Working definitions were developed for each attribute and are included in Appendix 1, along with at least three citations of illustrative studies collected in the literature review for the highest tier of each nested attribute added to the SES framework. Listed citations for each attribute are not presented as definitive authoritative sources nor as a comprehensive listing of all studies in which the attribute was identified. Rather, they represent examples of how scholars have applied the concept in other studies.

\section{RESULTS}

The SES framework organizes system attributes into nested tiers. The first-tier attributes of the SES framework, as defined for an urban stormwater management system, are summarized in Fig. 2. 
Table 1. Modified second- through fifth-tier attributes of the urban stormwater social-ecological system (SES) framework. Factors modified from McGinnis and Ostrom (2014), Epstein et al. (2013), and Vogt et al. (2015) that are specific for green infrastructure adoption in urban stormwater social-ecological systems are noted with italic font.

\begin{tabular}{|c|c|c|c|c|c|c|c|c|}
\hline $\begin{array}{l}\text { Social, economic, and } \\
\text { political settings (S) }\end{array}$ & $\begin{array}{l}\text { Ecological } \\
\text { rules (ER) }\end{array}$ & $\begin{array}{l}\text { Governance systems } \\
\text { (GS) }\end{array}$ & Actors (A) & Resource systems (RS) & Resource units (RU) & $\begin{array}{l}\text { Related ecosystems } \\
\text { (ECO) }\end{array}$ & Interactions (I) & Outcome criteria $(\mathrm{O})$ \\
\hline $\begin{array}{c}\text { S1 - } \\
\text { Economic development } \\
\text { S2 - } \\
\text { Demographic trends } \\
\text { S3 - } \\
\text { Political stability } \\
\text { S4 - } \\
\text { Government policies } \\
\text { S5 - } \\
\text { Market incentives } \\
\text { S6 - } \\
\text { Media organization } \\
\text { S7 - } \\
\text { Technology }\end{array}$ & $\begin{array}{c}\text { ER1 - } \\
\text { Physical rules } \\
\text { ER2 - } \\
\text { Chemical } \\
\text { rules } \\
\text { ER3 - } \\
\text { Biological } \\
\text { rules }\end{array}$ & 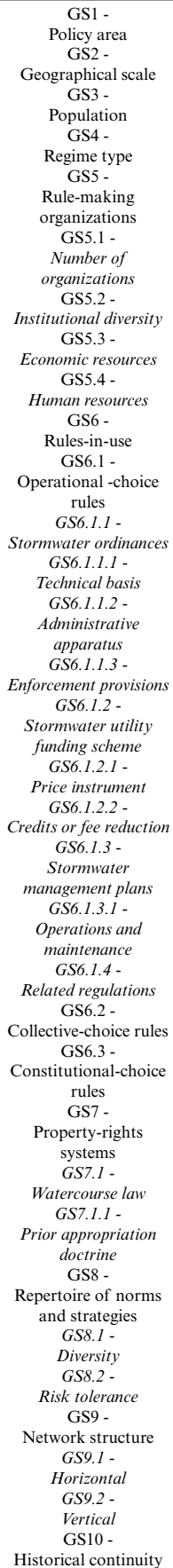 & 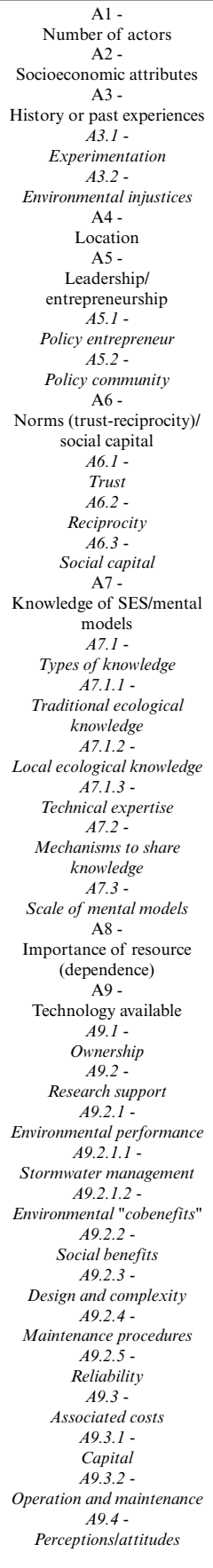 & $\begin{array}{c}\text { RS1 - } \\
\text { Sector } \\
\text { RS2 - } \\
\text { Clarity of system } \\
\text { boundaries } \\
\text { RS3 - } \\
\text { Size of resource } \\
\text { system - } \\
\text { RS4 - } \\
\text { Human-constructed } \\
\text { facilities } \\
\text { RS4.1 - } \\
\text { Locations } \\
\text { RS4.1.1 - } \\
\text { Availability for } \\
\text { potential facilities } \\
\text { RS4.2 - } \\
\text { Functionality } \\
\text { RS5 - } \\
\text { Productivity of system } \\
\text { RS6 - } \\
\text { Equilibrium properties } \\
\text { RS6.1 - } \\
\text { Frequency/timing of } \\
\text { disturbances } \\
\text { RS7 - } \\
\text { Predictability of } \\
\text { system dynamics } \\
\text { RS8 - } \\
\text { Storage characteristics } \\
\text { RS8.1 - } \\
\text { Soil characteristics } \\
\text { RS8.2 - } \\
\text { Imperviousness } \\
\text { RS9 - } \\
\text { Location } \\
\text { RS10 - } \\
\text { Ecological history } \\
\text { RS10.1 - } \\
\text { Human use and } \\
\text { disturbance }\end{array}$ & $\begin{array}{c}\text { RU1 - } \\
\text { Resource unit } \\
\text { mobility } \\
\text { RU2 - } \\
\text { Growth or } \\
\text { replacement rate } \\
\text { RU3 - } \\
\text { Interaction among } \\
\text { resource units } \\
\text { RU4 - } \\
\text { Economic value } \\
\text { RU5 - } \\
\text { Number of units } \\
\text { RU6 - } \\
\text { Distinctive } \\
\text { characteristics } \\
\text { RU7 - } \\
\text { Spatial and temporal } \\
\text { distribution }\end{array}$ & $\begin{array}{c}\text { ECO1- } \\
\text { Climate patterns } \\
\text { ECO2 - } \\
\text { Pollution patterns } \\
\text { ECO3 - } \\
\text { Flows into and out } \\
\text { of focal SES }\end{array}$ & $\begin{array}{c}\text { I1 - } \\
\text { Harvesting } \\
\text { I2 - } \\
\text { Information } \\
\text { sharing } \\
\text { I3 - } \\
\text { Deliberation } \\
\text { processes } \\
\text { I4 - } \\
\text { Conflicts } \\
\text { I5 - } \\
\text { Investment } \\
\text { activities } \\
\text { I6 - } \\
\text { Lobbying } \\
\text { activities } \\
\text { I7 - } \\
\text { Self-organizing } \\
\text { activities } \\
\text { I8 - } \\
\text { Networking } \\
\text { activities } \\
\text { I9 - } \\
\text { Monitoring } \\
\text { activities } \\
\text { I10 - } \\
\text { Evaluative } \\
\text { activities }\end{array}$ & $\begin{array}{c}\text { O1 - } \\
\text { Social performance } \\
\text { measures } \\
\text { O2 - } \\
\text { Ecological } \\
\text { performance } \\
\text { measures } \\
\text { O3 - } \\
\text { Externalities to other } \\
\text { SESs }\end{array}$ \\
\hline
\end{tabular}

The resource system (RS) is defined as an urban stormwater system; i.e., the system of water flows that results from wet weather. Multiple sets of resource units (RU) can be defined within an urban stormwater system, such as units of stormwater or the storage volumes available for stormwater throughout the system. The governance system (GS) includes the sets of rules agreed upon by national, state, and local organizations for managing urban stormwater. The actors (A) category includes individuals and groups that interact with the urban stormwater system. Multiple categories of actors can be defined, including 
individuals and groups that are involved in rule-making processes, and property owners that are affected by stormwater management decisions. Attributes from each of these categories provide inputs to action situations, where interactions (I) among actors transform these inputs into various outcomes, which can be measured by outcome criteria $(\mathrm{O})$. Additional influences flow between the focal SES attributes and related ecosystems (ECO); ecological rules (ER); and social, economic, and political settings (S).

Fig. 2. First tiers of social-ecological system framework for an urban stormwater social-ecological system (adapted from Ostrom [2007] and Epstein et al. [2013]).

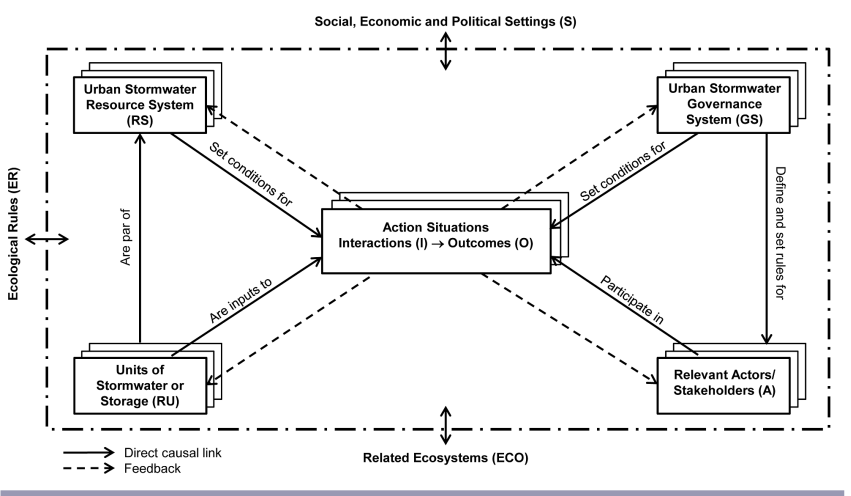

Table 1 summarizes the changes made to the SES framework. A detailed summary of the modifications, along with working definitions and illustrative references, are provided in Appendix 1. Because the study focus is only on changes related to resource management programs, the findings led to detailed expansions of multiple governance system and actor attributes. Attributes for RU, ECO, ER, and S were not modified beyond second-tier changes suggested by McGinnis and Ostrom et al. (2014) and Vogt et al. (2015), though many of these attributes have direct and important effects on the design of municipal stormwater management programs. Additional studies on implementing various technological designs may result in a more detailed account for influential attributes in these categories.

Multiple third-, fourth-, and fifth-tier variables were added to describe various attributes of stormwater management technologies that are available to actors within the SES (A9), such as research support (A9.2), associated costs (A9.3), and perceptions of particular technologies (A9.4). The addition of third-, fourth-, and fifth-tier variables related to humanconstructed facilities (RS4) designates both the types and functionalities of existing and potential stormwater infrastructure. A notable factor related to the construction of GI technologies is the availability of suitable locations for potential facilities (RS4.1.1), which is often associated with other factors such as local soil characteristics (RS8.1) (Shuster et al. 2014). Additional tiers allow for a detailed account of the assortment of resources and rules used by organizations to manage GI technologies. Stormwater ordinances (GS6.1.1) often acted as a barrier to GI implementation (Nowacek et al. 2003, Lassiter 2007, Stockwell 2009, Dochow 2013). Another common barrier was lack of sufficient program funding (Clean Water America Alliance 2011, Siglin 2012, Winz et al. 2014), which is associated with limited economic resources available to rule-making organizations (GS5.3), type of stormwater utility funding schemes (GS6.1.2), and socioeconomic attributes of actors (A2). Multiple attributes of actors that interact with and manage stormwater resources were found to influence GI program adoption, such as the leadership efforts of policy entrepreneurs (A5) and policy communities (A5.2), multiple actor knowledge types (A7.1), experimentation (i.e., technology pilot projects) (A3.1), and environmental injustices (A3.2).

\section{DISCUSSION}

In the broadest sense, integration of GI into an urban stormwater management system can be understood as the development of human-constructed facilities (RS4) across diffuse locations (RS4.1) using available technologies (A9) to alter the storage characteristics of an urban stormwater system (RS8). In developing this SES framework, additional third-, fourth-, and fifth-tier variables were needed to account for complex arrangements of social and biophysical factors that affect GI implementation. Operational-choice rules (GS6.1), such as ordinances, funding schemes, and comprehensive management plans, were found to be among the most complex factors. These rules are often further complicated by related SES regulations (GS6.1.4), such as zoning, building codes, and demolition practices (Lassiter 2007, Carter and Fowler 2008, Shuster et al. 2014). These related regulations are often managed by separate organizations, which may create barriers to GI implementation if the regulations are prohibitive. Property-rights systems that include prior-appropriation doctrines (GS7.1.1) can limit the choices of GI technologies (e.g., rainwater collection systems for some communities in the western United States) (Jensen 2008, Salkin 2009).

Funding was found to be among the most frequently cited barriers to GI (Godwin et al. 2008, Roy et al. 2008, Brown et al. 2009, Earles et al. 2009, Ruppert and Clark 2009, Stockwell 2009, Clean Water America Alliance 2011), most often in reference to the limited economic resources of enforcement organizations (GS5.1.1.2) and a lack of information on the cost-effectiveness of GI (A9.3). In the studies reviewed, stormwater management programs were enforced primarily by public organizations that selected stormwater management technologies to meet outcome criteria in a cost-effective manner. Environmental services associated with GI (A9.2.1.2), such as reducing urban heat island effects or promoting recreational opportunities, were cited as drivers for adoption when these benefits were quantifiable (Nowacek et al. 2003, Madden 2010). This suggests that it is difficult to maintain clear institutional boundaries when assessing the market and nonmarket value of GI because there may be additional benefits that GI can bring to a community beyond stormwater management.

The financial concerns of enforcement organizations are complicated by the design of effective stormwater utility funding schemes (GS6.1.2). Many funding schemes are predicated on the extent of total impervious area of urban land parcels because this metric has frequently been used to predict levels of surface water impairments due to stormwater runoff (Booth and Jackson 1997, Parikh et al. 2005). However, studies suggest that the subset of impervious surfaces that route runoff directly to surface waters via sewer pipes, known as directly connected impervious area or effective impervious area, may be responsible for most surface 
water impairments due to urbanization (Brabec et al. 2002, Walsh 2004, Walsh et al. 2005, Roy and Shuster 2009). Thus, stormwater utility funding schemes based on total impervious area rather than effective impervious area may not lead to desired SES outcomes. Additional limitations of utility funding schemes may develop if financial credits for GI are calculated as a one-time credit based on the initial installation without including ongoing performance and maintenance criteria, or if residential property owners are not included in financial incentive programs (Parikh et al. 2005).

Technological attributes are described in both the social and ecological domains of the SES framework. While it has been argued that there is no need to create a separate technological domain (McGinnis and Ostrom 2014), we demonstrate a need to more fully develop robust descriptions of technological attributes within urban stormwater SESs because these attributes act as key feedback mechanisms between the social and ecological domains. Historically, technological innovations in urban water SESs have been shown to bring about desired social and ecological regime shifts, such as a reduction in water-borne illness and a decrease in the frequency of algal blooms due to eutrophic states of receiving waters (Melosi 1999, Smith et al. 1999). Urban water infrastructure choices may also lead to unforeseen consequences over long periods. For example, combined sewer systems were once deemed to be the most appropriate choice for urban settings due to factors such as cost-effectiveness and availability of water courses for overflow disposal (Tarr 1979). These decisions have left a legacy of water pollution problems for many communities, as combined sewer overflows continue to impair surface waters and create human health hazards (USEPA 2004, Donovan et al. 2008, Gooré Bi et al. 2015). By developing a comprehensive categorization of technological attributes within an SES framework, policy-makers will be better equipped to make wellinformed decisions concerning technology selection for desired urban water SES outcomes.

Though additional characterizations were not added within several second-tier categories, such as resource units (RU) and outcome criteria $(\mathrm{O})$, attributes in these categories have important implications for stormwater management technology decisions. For instance, stormwater management plans are traditionally designed according to the spatial and temporal distribution of stormwater flows in an urban area (RU7), which will be affected by changes in local precipitation patterns (RU2). The spatial and temporal distribution of stormwater volumes within an urban setting places clear boundaries on which technologies should be considered and where they should be situated in an urban setting (Askarizadeh et al. 2015). Additionally, the criteria used to select stormwater management technologies, such as relative costeffectiveness or ecological performance measures, will often strongly influence enforcement officials' decision-making processes (Flynn et al. 2014). Expansion of these attribute categories may be necessary when considering research questions related to the design of specific stormwater technologies or the influence of particular outcome criteria.

Some limitations of the modified framework attributes should be noted. Because several programs reviewed in the literature are in early phases of development, some SES framework attributes are likely relevant to only nascent GI implementation. However, an analysis of GI technologies in urban stormwater SESs over longer timescales may result in other variables having a greater effect (Brown et al. 2013). Much of the research we reviewed relies on case study methods such as the solicitation of particular actors' perceptions. Thus, some factors listed may pertain to specific actors or institutions, such as engineering firms, municipal officials, developers, or community residents. Additional studies can provide further insights into the possibility of shared, complementary interactions among actors within specific situations that result in the development of successful GI programs. It is also important to note that while the literature review was not restricted to studies from particular geographic locations, most studies were based in the United States or Australia, which prescribe similar stormwater governance structures. Researchers who use the revised SES framework in studies of community-based stormwater governance regimes may need to add more detailed characterizations of particular attributes (such as property-rights systems or collective-choice rules), or may need to omit others (such as particular operational rules).

\section{CONCLUSION}

We developed a modified SES framework to recognize the combinations of influential variables related to the development of municipal urban stormwater management programs that feature extensive use of GI technologies. The modifications made to the SES framework revealed the need for additional attribute tiers related to variables such as available technologies, actor characterizations, and operational-choice rules. Our findings demonstrate that affecting change in the built structure of urban stormwater systems involves multiple interacting attributes of the actors and governance systems within an SES.

The framework we developed should be interpreted as a flexible, proposed framework rather than a definitive set of variables that will be relevant in all urban stormwater SES cases. Other studies highlight qualities of particular attributes within adapted SES frameworks to explore dynamic interactions and outcomes of interest (Fleischman et al. 2010, Basurto et al. 2013, Nagendra and Ostrom 2014, Leslie et. al 2015, Partelow and Boda 2015). The revised framework we presented highlights key factors of GI adoption that can be further explored using various theories and models to assess outcomes of interest related to urban stormwater SESs seeking to adopt GI technologies (Flynn et al. 2014). Tiers may be added or omitted to accommodate particular theories and research questions.

There is a need to explore the specific, contextual factors affecting the decision to adopt particular management approaches in urban stormwater SESs. The growing popularity of GI systems across municipalities carries a risk that these technologies will be perceived as a panacea for stormwater management (Ostrom 2007). However, there continues to be a need for a more sophisticated quantitative understanding of how GI technologies bring out particular SES outcomes. Neither a fully green nor entirely gray infrastructure approach to stormwater management will likely be optimal at any location. Instead, long-term solutions must be built around improved knowledge of factors influencing water quantity and quality in urban areas, and leveraging the services and capacities of both gray and green infrastructure. Such understanding should include the consideration of the unique characteristics of a particular urban water SES. 
Responses to this article can be read online at: http://www.ecologyandsociety.org/issues/responses. $\mathrm{php} / 8756$

\begin{abstract}
Acknowledgments:
This work was supported in part by NSF grant \#1444755, Urban Resilience to Extremes Sustainability Research Network. We also thank the SURDNA Foundation for providing funding for part of this work. We are grateful for the helpful feedback from Dr. Burnell Fischer, Dr. Jessica Vogt, and colleagues at The Vincent and Elinor Ostrom Workshop in Political Theory and Policy Analysis at Indiana University, Bloomington, Indiana. We are also indebted to the work of Elinor Ostrom.
\end{abstract}

\section{LITERATURE CITED}

Altheide, D., M. Coyle, K. DeVriese, and C. Schneide. 2008. Emergent qualitative document analysis. Pages 127-151 in S. N. Hesse-Biber, and P. Leavy, editors. Handbook of emergent methods. Guilford Press, New York, USA.

Askarizadeh, A., M. A. Rippy, T. D. Fletcher, D. L. Feldman, J. Peng, P. Bowler, A. S. Mehring, B. K. Winfrey, J. A. Vrugt, A. AghaKouchak, S. C. Jiang, B. F. Sanders, L. A. Levin, S. Taylor, and S. B. Grant. 2015. From rain tanks to catchments: use of lowimpact development to address hydrologic symptoms of the urban stream syndrome. Environmental Science \& Technology 49 (19):11264-11280. http://pubs.acs.org/doi/abs/10.1021/acs. est.5b01635 http://dx.doi.org/10.1021/acs.est.5b01635

Basurto, X., S. Gelcich, and E. Ostrom. 2013. The socialecological system framework as a knowledge classificatory system for benthic small-scale fisheries. Global Environmental Change 23 (6):1366-1380. http://dx.doi.org/10.1016/j.gloenvcha.2013.08.001

Berkes, F., C. Folke, and J. Colding. 1998. Linking social and ecological systems: management practices and social mechanisms for building resilience. Cambridge University Press, Cambridge, UK.

Binder, C. R., J. Hinkel, P. W. G. Bots, and C. Pahl-Wostl. 2013. Comparison of frameworks for analyzing social-ecological systems. Ecology and Society 18(4):26. http://dx.doi.org/10.5751/ ES-05551-180426

Booth, D. B., and C. R. Jackson. 1997. Urbanization of aquatic systems: degradation thresholds, stormwater detection, and the limits of mitigation. Journal of the American Water Resources Association 33(5):1077-1090. http://dx.doi.org/10.1111/j.1752-1688.1997. tb04126.X

Brabec, E., S. Schulte, and P. L. Richards. 2002. Impervious surfaces and water quality: a review of current literature and its implications for watershed planning. Journal of Planning Literature 16(4):499-514. http://dx.doi.org/10.1177/088541202400903563

Brown, R., M. Farrelly, and N. Keath. 2009. Practitioner perceptions of social and institutional barriers to advancing a diverse water source approach in Australia. Water Resources Development 25(1):15-28. http://dx.doi.org/10.1080/07900620802586090
Brown, R. R., M. A. Farrelly, and D. A. Loorbach. 2013. Actors working the institutions in sustainability transitions: the case of Melbourne's stormwater management. Global Environmental Change 23(4):701-718. http://dx.doi.org/10.1016/j.gloenvcha.2013.02.013

Carter, T., and L. Fowler. 2008. Establishing green roof infrastructure through environmental policy instruments. Environmental Management 42:151-164. http://dx.doi.org/10.1007/ $\underline{\mathrm{s} 00267-008-9095-5}$

Cinner, J. E., T. R. McClanahan, M. A. MacNeil, N. A. J. Graham, T. M. Daw, A. Mukminin, D. A. Feary, A. L. Rabearisoa, A. Wamukota, N. Jiddawi, S. J. Campbell, A. H. Baird, F. A. Januchowski-Hartley, S. Hamed, R. Lahari, T. Morove, and J. Kuange. 2012. Comanagement of coral reef social-ecological systems. Proceedings of the National Academy of Sciences of the United States of America 109(14):5219-5222. http://dx.doi. org/10.1073/pnas.1121215109

Clean Water America Alliance. 2011. Barriers and gateways to green infrastructure. Washington, D.C., USA. [online] URL: http://uswateralliance.org/sites/uswateralliance.org/files/publications/ Barriers-and-Gateways-to-Green-Infrastructure.pdf

Coles, J. F., G. McMahon, A. H. Bell, L. R. Brown, F. A. Fitzpatrick, B. S. Eikenberry, M. D. Woodside, T. F. Cuffney, W. L. Bryant, K. Cappiella, L. Fraley-McNeal, and W. P. Stack. 2012. Effects of urban development on stream ecosystems in nine metropolitan study areas across the United States. U.S. Geological Survey Circular 1373. [online] URL: http://pubs.usgs.gov/ circ/1373/pdf/Circular1373.pdf

De Sousa, M. R. C., F. A. Montalto, and S. Spatari. 2012. Using life cycle assessment to evaluate green and grey combined sewer overflow control strategies. Journal of Industrial Ecology 16 (6):901-913. http://dx.doi.org/10.1111/j.1530-9290.2012.00534. $\underline{\mathrm{x}}$

Dochow, D. 2013. Transforming tradition: a case study of stormwater management in Clark County, Washington to assess barriers to low impact development strategies. Thesis. Evergreen State College, Olympia, Washington, U.S.A. [online] URL: http:// archives.evergreen.edu/masterstheses/Accession86-10MES/ Dochow D2013.pdf

Dominguez, D., B. Truffer, and W. Gujer. 2011. Tackling uncertainties in infrastructure sectors through strategic planning: the contribution of discursive approaches in the urban water sector. Water Policy 13(3):299-316. http://dx.doi.org/10.2166/ wp.2010.109

Donovan, E., K. Unice, J. D. Roberts, M. Harris, and B. Finley. 2008. Risk of gastrointestinal disease associated with exposure to pathogens in the water of the Lower Passaic River. Applied and Environmental Microbiology 74:994-1003. http://dx.doi.org/10.1128/ AEM.00601-07

Earles, A., D. Rapp, J. Clary, and J. Lopitz. 2009. Breaking down the barriers to low impact development in Colorado. Pages 1-10 in S. Starrett, editor. World Environmental and Water Resources Congress 2009: Great Rivers, May 2009. http://dx.doi. org/10.1061/41036(342)91

Epstein, G., J. M. Vogt, S. K. Mincey, M. Cox, and B. Fischer. 2013. Missing ecology: integrating ecological perspectives with 
the social-ecological system framework. International Journal of the Commons 7(2):432-453. http://dx.doi.org/10.18352/ijc.371

Ferguson, B. C., R. R. Brown, and A. Deletic. 2013. Diagnosing transformative change in urban water systems: theories and frameworks. Global Environmental Change 23(1):264-280. http:// dx.doi.org/10.1016/i.gloenvcha.2012.07.008

Fleischman, F., K. Boenning, G. A. Garcia-Lopez, S. Mincey, M. Schmitt-Harsh, K. Daedlow, M. C. Lopez, X. Basurto, B. Fischer, and E. Ostrom. 2010. Disturbance, response, and persistence in self-organized forested communities: analysis of robustness and resilience in five communities in southern Indiana. Ecology and Society 15(4):9. [online] URL: http://www.ecologyandsociety. org/vol15/iss4/art9/

Fletcher, T. D., W. Shuster, W. F. Hunt, R. Ashley, D. Butler, S. Arthur, S. Trowsdale, S. Barraud, A. Semadeni-Davies, J.-L. Bertrand-Krajewski, P. S. Mikkelsen, G. Rivard, M. Uhl, D. Dagenais, and M. Viklander. 2014. SUDS, LID, BMPs, WSUD and more - the evolution and application of terminology surrounding urban drainage. Urban Water Journal 12:1-18.

Flynn, C. D., C. I. Davidson, and J. Mahoney. 2014. Transformational changes associated with sustainable stormwater management practices in Onondaga County, New York. Pages 89-100 in J. Crittenden, C. Hendrickson, and B. Wallace, editors. ICSI 2014: creating infrastructure for a sustainable world. http:// ascelibrary.org/doi/abs/10.1061/9780784478745.009

Godwin, D., B. L. Parry, F. A. Burris, S. S. Chan, and A. Punton. 2008. Barriers and opportunities for low impact development: case studies from three Oregon communities. Oregon State University, Corvallis, Oregon, USA. [online] URL: http://seagrant. oregonstate.edu/sites/default/files/sgpubs/onlinepubs/w06002.pdf

Gooré Bi, E., F. Monette, and J. Gasperi. 2015. Analysis of the influence of rainfall variables on urban effluents concentrations and fluxes in wet weather. Journal of Hydrology 523:320-332. http://dx.doi.org/10.1016/j.jhydrol.2015.01.017

Gutiérrez, N. L., R. Hilborn, and O. Defeo. 2011. Leadership, social capital and incentives promote successful fisheries. Nature 470(7334):386-389. http://dx.doi.org/10.1038/nature09689

Hatt, B. E., T. D. Fletcher, C. J. Walsh, and S. L. Taylor. 2004. The influence of urban density and drainage infrastructure on the concentrations and loads of pollutants in small streams. Environmental Management 34:112-124. http://dx.doi.org/10.1007/ $\underline{\mathrm{s} 00267-004-0221-8}$

Holling, C. S., and L. H. Gunderson. 2002. Panarchy: understanding transformations in human and natural systems. Island Press, Washington D.C., USA.

Jensen, M. A. 2008. Feasibility of rainwater harvesting for urban water management in Salt Lake City. Thesis. University of Utah, Salt Lake City, Utah, USA. [online] URL: http://content.lib.utah. edu/utils/getfile/collection/etd2/id/1406/filename/image

Lassiter, R. 2007. An assessment of impediments to low-impact development in the Virginia portion of the Chesapeake Bay watershed. Thesis. Virginia Commonwealth University, Richmond, Virginia, USA. [online] URL: http://scholarscompass. vcu.edu/cgi/viewcontent. .cgi?article $=1891 \&$ context $=$ etd
Leslie, H. M., X. Basurto, M. Nenadovic, L. Sievanen, K. C. Cavanaugh, J. J. Cota-Nieto, B. E. Erisman, E. Finkbeiner, G. Hinojosa-Arango, M. Moreno-Báez, and S. Nagavarapu, S. M. W. Reddy, A. RodrÃguezf, K. Siegel, J. J. Ulibarria-Valenzuela, A. Hudson Weaver, and O. Aburto-Oropeza. 2015. Operationalizing the social-ecological systems framework to assess sustainability. Proceedings of the National Academy of Sciences of the United States of America 112(19):5979-5984. http://dx.doi.org/10.1073/pnas.1414640112

Madden, S. A. 2010. Choosing green over gray: Philadelphia's innovative stormwater infrastructure plan. Thesis. Massachusetts Institute of Technology, Cambridge, Massachusetts, USA. [online] URL: http://www.mit.edu/afs.new/athena/dept/cron/ project/urban-sustainability/Stormwater Sarah\%20Madden/ sarahmadden thesis_MIT.pdf

Marshall, G. 2015. A social-ecological systems framework for food systems research: accommodating transformation systems and their products. International Journal of the Commons 9:881908. http://dx.doi.org/10.18352/ijc.587

McGinnis, M. D., and E. Ostrom. 2014. Social-ecological framework: initial changes and continuing challenges. Ecology and Society 19(2):30. [online] URL: http://dx.doi.org/10.5751/ ES-06387-190230

Melosi, M. V. 1999. The sanitary city: urban infrastructure in American from colonial times to the present. Johns Hopkins University Press, Baltimore, Maryland, USA.

Nagendra, H., and E. Ostrom. 2014. Applying the socialecological system framework to the diagnosis of urban lake commons in Bangalore, India. Ecology and Society 19(2):67. http://dx.doi.org/10.5751/ES-06582-190267

National Research Council. 2009. Urban stormwater management in the United States. National Academies Press, Washington, D. C., USA [online] URL: http://www.nap.edu/catalog/12465/ urban-stormwater-management-in-the-united-states

Novotny, V., J. Ahern, and P. Brown. 2010. Water centric sustainable communities: planning, retrofitting and building the next urban environment. John Wiley \& Sons, Hoboken, New Jersey, USA. http://dx.doi.org/10.1002/9780470949962

Nowacek, D., E. Nelson, and J. Petchenik. 2003. Social and institutional barriers to stormwater infiltration. Wisconsin Department of Natural Resources-Bureau of Integrated Science Services. [online] URL: http://www.kitsaplid.org/resources/ Barriers to SW Infiltration.pdf

Ostrom, E. 2007. A diagnostic approach for going beyond panaceas. Proceedings of the National Academy of Sciences of the United States of America 104(39):15181-15187. http://dx.doi. org/10.1073/pnas.0702288104

Ostrom, E. 2009. A general framework for analyzing sustainability of social-ecological systems. Science 325 (5939):419-422. http://dx.doi.org/10.1126/science.1172133

Ostrom, E., M. Cox, and E. Schlager. 2014. An assessment of the institutional analysis and development framework. Pages 267306 in P. A. Sabatier, and C. Weible, editors. Theories of the Policy Process. Third edition. Westview Press, Colorado, USA. 
Pahl-Wostl, C. 2007. Transitions towards adaptive management of water facing climate and global change. Water Resources Management 21(1):49-62. http://dx.doi.org/10.1007/s11269-006-9040-4

Pahl-Wostl, C., G. Holtz, B. Kastens, and C. Knieper. 2010. Analyzing complex water governance regimes: the management and transition framework. Environmental Science \& Policy 13 (7):571-581. http://dx.doi.org/10.1016/j.envsci.2010.08.006

Parikh, P., M. A. Taylor, T. Hoagland, H. Thurston, and W. Shuster. 2005. Application of market mechanisms and incentives to reduce stormwater runoff: an integrated hydrologic, economic and legal approach. Environmental Science \& Policy 8(2):133-144. http://dx.doi.org/10.1016/j.envsci.2005.01.002

Partelow, S., and C. Boda. 2015. A modified diagnostic socialecological system framework for lobster fisheries: case implementation and sustainability assessment in Southern California. Ocean \& Coastal Management 114:204-217. http://dx. doi.org/10.1016/j.ocecoaman.2015.06.022

Pyke, C., M. P. Warren, T. Johnson, J. LaGro Jr., J. Scharfenberg, P. Groth, R. Freed, W. Schroeer, and E. Main. 2011. Assessment of low impact development for managing stormwater with changing precipitation due to climate change. Landscape and Urban Planning 103(2):166-173. http://dx.doi.org/10.1016/j. landurbplan.2011.07.006

Roy, A. H., and W. D. Shuster. 2009. Assessing impervious surface connectivity and applications for watershed management. Journal of the American Water Resources Association 45(1):198-209. http://dx.doi.org/10.1111/j.1752-1688.2008.00271.x

Roy, A. H., S. J. Wenger, T. D. Fletcher, C. J. Walsh, A. R. Ladson, W. D. Shuster, H. W. Thurston, and R. R. Brown. 2008. Impediments and solutions to sustainable, watershed-scale urban stormwater management: lessons from Australia and the United States. Environmental Management 42(2):344-359. http://dx.doi. org/10.1007/s00267-008-9119-1

Ruppert, T., and M. Clark. 2009. Understanding and overcoming legal and administrative barriers to LID: a Florida case study. Pages 1-10 in N. She and M. Char, editors. Low impact development for urban ecosystem and habitat protection. International Low Impact Development Conference 2008, Seattle, Washington, USA, November 16-19, 2008. http://dx.doi. org/10.1061/41009(333)50

Salkin, P. E. 2009. Sustainability and land use planning: greening state and local land use plans and regulations to address climate change challenges and preserve resources for future generations. William and Mary Environmental Law and Policy Review 34:121.

Shuster, W. D., S. Dadio, P. Drohan, R. Losco, and J. Shaffer. 2014. Residential demolition and its impact on vacant lot hydrology: implications for the management of stormwater and sewer system overflows. Landscape and Urban Planning 125:4856. http://dx.doi.org/10.1016/j.landurbplan.2014.02.003

Shuster, W. D., and A. S. Garmestani. 2015. Adaptive exchange of capitals in urban water resources management: an approach to sustainability? Clean Technologies and Environmental Policy 17 (6):1393-1400. http://dx.doi.org/10.1007/s10098-014-0886-5

Siglin, D. D. 2012. Municipal use of green stormwater infrastructure in the Delaware River Basin: barriers, drivers, and opportunities for implementation. Thesis. Pennsylvania State
University, Pennsylvania, USA. [online] URL: https://etda. libraries.psu.edu/paper/15290/12231

Smith, V. H., G. D. Tilman, and J. C. Nekola. 1999. Eutrophication: impacts of excess nutrient inputs on freshwater, marine, and terrestrial ecosystems. Environmental Pollution 100:179-196. http://dx.doi.org/10.1016/S0269-7491(99)00091-3

Stockwell, A. 2009. Analysis of barriers to low impact development in the North Coast Redwood Region, California. Thesis. Humboldt State University, Arcata, California, USA. [online] URL: $\underline{\text { http:// }}$ humboldt-dspace.calstate.edu/bitstream/handle/2148/595/ stockwell thesis 2.12.10 FINAL2.pdf?sequence=1

Tarr, J. A. 1979. The separate vs. combined sewer problem: a case study in urban technology design choice. Journal of Urban History 5(3):308-339.

Tzoulas, K., K. Korpela, S. Venn, V. Yli-Pelkonen, A. Kaźmierczak, J. Niemela, and P. James. 2007. Promoting ecosystem and human health in urban areas using green infrastructure: a literature review. Landscape and Urban Planning 81(3):167-178. http://dx.doi.org/10.1016/j.landurbplan.2007.02.001

United States Environmental Protection Agency (USEPA). 2004. Report to Congress: impacts and control of CSOs and SSOs. No. EPA 833-R-04-001.

Villarreal, E. L., A. Semadeni-Davies, and L. Bengtsson. 2004. Inner city stormwater control using a combination of best management practices. Ecological Engineering 22:279-298. http:// dx.doi.org/10.1016/j.ecoleng.2004.06.007

Vogt, J. M., G. B. Epstein, S. K. Mincey, B. C. Fischer, and P. McCord. 2015. Putting the "E" in SES: unpacking the ecology in the Ostrom social-ecological system framework. Ecology and Society 20(1):55. http://dx.doi.org/10.5751/ES-07239-200155

Walker, B., C. S. Holling, S. R. Carpenter, and A. Kinzig. 2004. Resilience, adaptability and transformability in social-ecological systems. Ecology and Society 9(2):5. [online] URL: http://www. ecologyandsociety.org/vo19/iss2/art5/

Walsh, C. J. 2004. Protection of in-stream biota from urban impacts: minimise catchment imperviousness or improve drainage design? Marine \& Freshwater Research 55(3):317-326. http://dx.doi.org/10.1071/mf03206

Walsh, C. J., T. D. Fletcher, and A. R. Ladson. 2005. Stream restoration in urban catchments through redesigning stormwater systems: looking to the catchment to save the stream. Journal of the North American Benthological Society 24(3):690-705. http:// dx.doi.org/10.1899/04-020.1

Wendel, H. E. W., J. A. Downs, and J. R. Mihelcic. 2011. Assessing equitable access to urban green space: the role of engineered water infrastructure. Environmental Science \& Technology 45:67286734. http://dx.doi.org/10.1021/es103949f

Wiek, A., and K. L. Larson. 2012. Water, people, and sustainability - a systems framework for analyzing and assessing water governance regimes. Water Resource Management 26 (11):3153-3171. http://dx.doi.org/10.1007/s11269-012-0065-6

Winz, I., S. Trowsdale, and G. Brierley. 2014. Understanding barrier interactions to support the implementation of sustainable urban water management. Urban Water Journal 11(6):497-505. http://dx.doi.org/10.1080/1573062x.2013.832777 
APPENDIX 1. Modified social-ecological system framework for urban stormwater systems with working definitions and references. Supplemental Information

Table 1: Modified framework for green infrastructure adoption in urban stormwater social-ecological systems. References provided as working definitions and illustrative examples from the literature.

Tier Level

Attribute

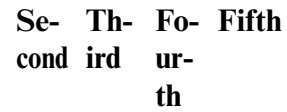

Biological rules

Social, economic, and political settings (S)

$\mathrm{S} 1$

$\mathrm{S} 2$

S3

S4

S5

S6

S7

\section{Economic development \\ Demographic trends} Political stability

Government policies

Market incentives

\section{Working Definition}

The broader context of laws, theories, and Epstein et al. principles developed in the natural sciences

Laws, theories, and principles of or relating to nature and properties of matter and energy

Laws, theories, and principles of or relating to composition, structure, properties, and change of matter Laws, theories, and principles of or relating to living organisms

The broader context within which the governance system per se is located, including the effects of market dynamics and cultural change

Efforts that seek to improve the economic well-being and quality of life for a community

Developments and changes in human populations

Degree of durability and integrity of a current government regime

Sets forth policies that address public issues related to, or otherwise effect, stormwater flows

Policies that incentivize certain stormwater management approaches

Characteristics of entities engaged in disseminating information to the general public through mass communication channels

Broader cultural settings and development context that affect the technologies regularly used by actors in their interactions with the resource units

\section{Definition \\ References $^{\dagger}$, and \\ Select Illustrative \\ Examples}

$(2013)^{\dagger}$

McGinnis (2011) ${ }^{\dagger}$

Madden (2010)

Winz et al.

$(2014)^{\ddagger}$

Travaline et al.

$(2015)^{\ddagger}$

Roy et al. (2008), Dunn (2010), Dochow (2013) Holloway et al. (2014)

Carter and

Fowler (2008) Dunn $(2010)^{\ddagger}$,

Clean Water

America Alliance

(2011) ${ }^{\ddagger}$, Dochow

$(2013)^{\ddagger}$

Madden (2010)

Cettner et al. (2014) ${ }^{b}$

Clean Water America Alliance (2011) ${ }^{\ddagger}$, Siglin

(2012) ${ }^{\ddagger}$, Cettner et al. $(2014 b)^{*}$ 


\section{Resource Units (RU)}

$\mathrm{U} 1$

R-

$\mathrm{U} 2$

R-

U3

R-

$\mathrm{U} 4$

R-

U5

R-

U6

$\mathrm{R}-$

$\mathrm{U} 7$

Resource systems (RS)

RS1

RS2

RS3

RS4

RS-

4.1

$\mathrm{R}-$

S4-

.1 .1

RS-

4.2
Characteristics of the units extracted

McGinnis (2011)

from a resource system, which can then be consumed or used as an input in production or exchanged for other goods or services.

Resource unit
mobility
Growth or
replacement rate

Ability for resource units to move throughout the resource system Absolute or relative descriptions of changes in quantities $(\mathrm{x})$ of resource units over time $(\mathrm{t})$

Basurto et al. $(2013)^{\dagger}$, Clean Water America Alliance (2011)

Interaction among Interactions among resource units during resource units different time periods affecting the future structure of the population

Economic value

Value of resource units in relation to the portfolio of resources available to actors

Basurto et al.

$(2013)^{\dagger}$

Basurto et al. $(2013)^{\dagger}$, Clean Water America Alliance (2011)

Number of units

Amount of individual resource units in resource system

Characteristics that can be identified in resource units and affect actors' behavior toward them

Allocation patterns of resource units across a geographic area in a particular time period

The biophysical system from which resource units are extracted and through which the levels of the focal resource are regenerated by natural dynamic processes Characteristic(s) of a resource system that Ostrom (2007) ${ }^{\dagger}$ distinguishes it from other resource systems

Clarity of system Biophysical characteristics that make boundaries

feasible for actors to determine where the resource system starts or ends

Size of resource Absolute or relative descriptions of the system spatial extent of a resource system Facilities produced by actors that affect

Humanthe resource system

facilities

Spatial extent where facilities are constructed by actors

Perez-Pedini et al. $(2005)^{\ddagger}$, Montalto et al. (2013)

Askarizadeh et al. $(2015)^{\ddagger}$

Clean Water

America Alliance $(2011)^{\ddagger}$, Hammitt

(2010) , Shuster et al. $(2014)^{\ddagger}$

Degree to which stormwater management Nowacek et al. facilities achieve desired outcomes $(2003)^{\ddagger}$, Siglin

$(2012)^{\ddagger}$, Keeley et

al. $(2013)^{\ddagger}$, Flynn

et al. (2014) 
RS5

RS6

RS-

6.3

RS7

RS8

RS-

8.1

RS-

8.2

RS9

RS-

10

RS-

10.3

Governance systems (GS)

GS1

Policy area

GS2

Geographical
Productivity of system

Equilibrium properties

Frequency/timing of disturbances

\section{Predictability of} system dynamics

Storage characteristics Soil characteristics

\section{Impervious} surface area

Location

Ecosystem history

Human use and disturbance
Degree to which actors are able to forecast or identify patterns in environmentally driven variability on recruitment

Degree to which the resource units can be retained or detained Hydrologic characteristics of soils

Amount of system coverage by materials that inhibit water infiltration

Spatial and temporal extent where resource units are found by actors

Past interactions that affect current actors' behaviors and stormwater management plans

Past interactions in which actors have greatly degraded resource system quality

The prevailing set of processes or institutions through which the rules shaping the behavior of the actors are set and revised

Rule systems tailored for a particular area of knowledge, geography, or time scale of governance system

Clean Water

America Alliance $(2011)^{\ddagger}$,

Askarizadeh et al. $(2015)^{\ddagger}$

Madden (2010) Clean Water

America Alliance $(2011)^{\ddagger}$, Keeley et al. $(2013)^{\ddagger}$,

Cettner et al.

$(2014 a)^{*}$

Basurto et al.

(2013) $)^{\dagger}$

Askarizadeh et al. (2015)

Nowacek et al. $(2003)^{\ddagger}$, Clean

Water America Alliance (2011) Shuster et al. $(2014)^{\ddagger}$, Rhea et al. $(2014)^{ \pm}$

Dietz and Clausen (2008) Roy and Shuster $(2009)^{\ddagger}$, Kertesz et al. $(2014)^{\ddagger}$

Hammitt (2010) Madden (2010),

Askarizadeh et al. (2015)

Shandas and Messer, (2008)*, Hammitt (2010) Madden (2010) Flynn et al. (2014)

McGinnis (2011) ${ }^{\dagger}$

Basurto et al. (2013) ${ }^{\dagger}$, Holloway et al. (2014)

McGinnis and Ostrom (2014) ${ }^{\dagger}$, Nowacek et al. (2003) $)^{\ddagger}$, Siglin (2012) $)^{\ddagger}$, Stockwell (2009) 
G-

G-

S6-

.1 .1

GS6.- Technical basis 1.1.1

GS6.- Administrative 1.1.2 apparatus

Rule-making organizations

Number of organizations

Institutional diversity

Economic resources

Rules-in-use

Operationalchoice rules

\section{Stormwater ordinances and regulations}

Defined group of people that participates in, or is subject to, the system of governance

Specifies the logic upon which the overarching governance system is organized

Human resources
Institutions recognized by external actors and/or authorities that facilitate formal structured interactions among actors affected by these institutions Number of organizations affecting decision-making processes related to stormwater management in the watershed

Degree of variation represented among rule-making organizations (including public sector, private sector, nongovernmental, community-based, or hybrid organizations)

Funds available to an organization that are used for the creation, operation and maintenance of the stormwater management program. Funds may be generated through a variety of means such as a variety of taxes, service charges, exactions, assessments, grants, loans, and bonds.

Human capital available to an organization for the creation, operation and maintenance of the stormwater management program.

Regulations or principles that specify the values of the working components of an action situation, each of which has emerged as the outcome of interactions in an adjacent action situation at a different level of analysis or arena of choice. Set of regulations or principles governing the implementation of practical decisions by individuals authorized or allowed to take these actions, often as a result of collective choice processes

Sets forth public policies directly related to drainage, flood control, and water quality aspects of stormwater, as well as the legal framework for permitting implementation of the controls. Performance standards, design criteria and information provided by rule-making organizations to assist designers in complying with ordinances and regulations.

Required procedures, such as approvals, permits, and inspections, to ensure that measures meet technical and legal requirements
McGinnis and

Ostrom (2014) ${ }^{\dagger}$

McGinnis and

Ostrom (2014)

McGinnis and

Ostrom (2014) $)^{\dagger}$

Madden (2010) (Shuster et al., 2008) Hammitt $(2010)^{*}$, Keeley et al. $(2013)^{\ddagger}$

Stockwell (2009) Hammitt (2010) Keeley et al. $(2013)^{+}$

Debo and Reese (2003) $)^{\dagger}$, (Clean Water America Alliance (2011) Keeley et al. (2013)

Roy et al. (2008) Stockwell (2009), Winz et al.

(2014)

Ostrom et al. $(1994)^{\dagger}$, Clean Water America Alliance (2011) Winz et al. $(2014)^{\dagger}$

McGinnis (2011) $)^{\dagger}$, Hammitt $(2010)^{\ddagger}$

Debo and Reese (2003) ${ }^{\dagger}$, Hammitt (2010) ${ }^{\ddagger}$, Madden (2010) ${ }^{\ddagger}$, Siglin (2012)

Debo and Reese

$(2003)^{\dagger}$, Roy et al. (2008) ${ }^{\ddagger}$, Hammitt $(2010)^{\ddagger}$, Dochow (2013)

Debo and Reese $(2003)^{\dagger}$, Jaffe et al. $(2010)^{\ddagger}$, Kulkarni, (2012) Dochow (2013) 


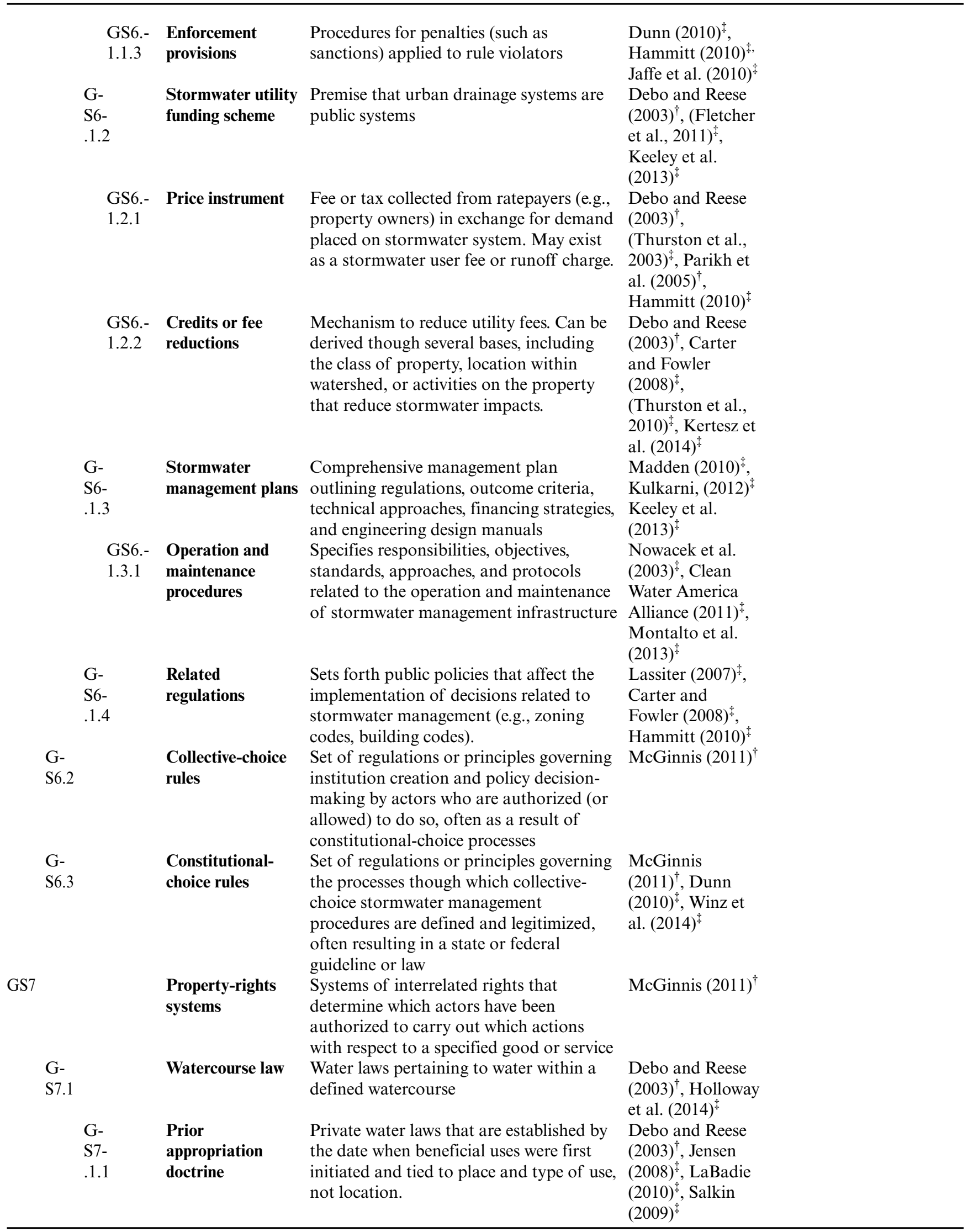


GS8

G-

S8.1

G-

S8.2

GS9

G-

S9.1

G-

S9.2

G-

S10

Actors (A)

A1

A2

A3

1

Repertoire of norms and strategies

Diversity

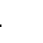

Network structure The connections among the rule-making organizations and the population subject to these rules

Horizontal

Connections that link actors with each other to act collectively for a common purpose

Vertical

Historical continuity

Number of relevant actors

Socioeconomic attributes

History or past experiences

Experimentation

A3-

.1

A3-

.2

Collection of actions and behaviors that actors regularly use, as shaped by the broader social and cultural setting

Degree of diversity in norms and strategies related to stormwater management decisions

Degree to which actors are willing to take action in spite of uncertainties

Connections that link actors with other organizations across levels

The length of time for which a particular form of governance has been in place Attributes of the individuals or groups that interact with resource units Number of actors affecting decisionmaking processes related to stormwater management in the watershed

Characteristics of actors related to social and economic dimensions affecting stormwater management plans

Past interactions that affect current actors' behaviors and stormwater management plans

Environmental justice
Variations in use patterns to increase knowledge of stormwater system dynamics (e.g., demonstration projects)

Degree to which the development, implementation, and enforcement of stormwater management plans reflect a fair treatment and meaningful involvement of all people regardless of race, color, national origin, or income
McGinnis and

Ostrom $(2014)^{\dagger}$,

Cettner et al.

$(2014 a)^{\ddagger}$, Cote

and Wolfe (2014)

Nowacek et al.

(2003) ${ }^{\ddagger}$, Hammitt

(2010) $)^{\ddagger}$, Madden

$(2010)^{\ddagger}$, Winz et

al. $(2014)^{\ddagger}$

(Singh, 2006)

Olorunkiya et al.

$(2012)^{\ddagger}$, Cettner et al. $(2014 a)^{\ddagger}$

McGinnis and

Ostrom (2014) ${ }^{a}$,

Madden (2010)

Cettner et al.

$(2014)^{\ddagger}$, Winz et

al. $(2014 \mathrm{a})^{\ddagger}$

Shandas and

Messer, (2008)

Madden (2010)

Keeley et al.

(2013)

Hammitt (2010),

Dochow (2013)

Keeley et al.

$(2013)^{\ddagger}$, Shuster et al. $(2008)^{*}$

McGinnis and

Ostrom (2014) ${ }^{\dagger}$

McGinnis and

Ostrom (2014) ${ }^{\dagger}$

Madden (2010)

Keeley et al.

(2013) $)^{\ddagger}$, Holloway

et al. (2014)

Hammitt (2010) Montalto et al.

(2013) al. $(2013)^{\ddagger}$,

Travaline et al. $(2015)^{\frac{1}{4}}$

Montalto et al.

$(2013)^{\ddagger}$, Baptiste

(2014) ${ }^{\ddagger}$, Baptiste

et al. $(2015)^{\ddagger}$,

Travaline et al.

$(2015)^{\ddagger}$

Madden (2010)

Shuster et al.,

(2013) ${ }^{\ddagger}$, Marks

(2014)

Perreault et al.

(2012) $)^{\ddagger}$, Flynn et

al. $(2014)^{\ddagger}$, Wolch

et al. (2014) 
A6.3

A7.1

Aknowledge

7.1.1
Reciprocity

Knowledge of SES/mental models

Types of Traditional

Location

Leadership/ entrepreneurship

Policy entrepreneur

Norms (trustreciprocity) and social capital

Trust

Social capital ecological knowledge
Physical place where actors are in relation to components of the resource system Actors who have skills useful to organize collective action and are followed by their peers/ Non-exertion of power particularly of the public/

Individuals who introduce and advocate for policy alternatives in many different settings, and invest time and energy to increase the chances for an idea to be placed on the decision agenda

Group composed of specialists in a given policy area developing policy alternatives

Degree by which one or several individuals can draw upon or rely on others for support or assistance in times of need

Measure of the extent to which members of a community feel confident that other members will not take maximum advantage of their vulnerabilities and/or live up to their agreements even if doing so may not be in their immediate interest.

Norm of behavior that encourages members of a group to cooperate with others who have cooperated with them in previous encounters.

Resources that an individual can draw upon in terms of relying on others to provide support or assistance in times of need, or a group's aggregate supply of such potential assistance, as generated by stable networks of important interactions among members of that community. Degree to which actors understand and make sense of the characteristics and/or dynamics of the SES

Types of knowledge actors use to understand SES

Degree to which actors make use of the cumulative body of knowledge, practices and beliefs evolving by adaptive processes and handed down through generations by cultural transmissions about the relationship of living beings (including humans) with one another and with their environment
Thurston et al. $(2010)^{\ddagger}$

Hammitt $(2010)^{\ddagger}$, Winz et al. $(2014)^{\dot{\dagger}}$

Kingdon (1995) ${ }^{\dagger}$, Godwin et al. $(2008)^{\ddagger}$, Madden $(2010)^{\ddagger}$, Flynn et al. $(2014)^{\ddagger}$

Kingdon (1995) ${ }^{\dagger}$, Shandas and Messer, $(2008)^{\ddagger}$,

Madden (2010)

Flynn et al. $(2014)^{\ddagger}$

Hammitt (2010) Cettner et al., $(2014 b)^{\ddagger}$, Winz et al. $(2014)^{\ddagger}$

McGinnis $(2011)^{\dagger}$, Nowacek et al. $(2003)^{\ddagger}$, Shandas and Messer, (2008) Flynn et al. (2014) $)^{\ddagger}$, Travaline et al. $(2015)^{\ddagger}$

McGinnis (2011) ${ }^{\dagger}$, Shandas and Messer, $(2008)^{\ddagger}$, Clean Water America Alliance (2011) McGinnis (2011) $)^{\dagger}$, Roy et al. $(2008)^{\ddagger}$, Dochow $(2013)^{\ddagger}$, Green et al. $(2012)^{\ddagger}$

Basurto et al. $(2013)^{\dagger}$, Clean Water America Alliance (2011)

Berkes (2012) ${ }^{\dagger}$, Mbilinyi et al., $(2005)^{\ddagger}$, Flynn et al. $(2014)^{\ddagger}$, Winz et al. (2014) 


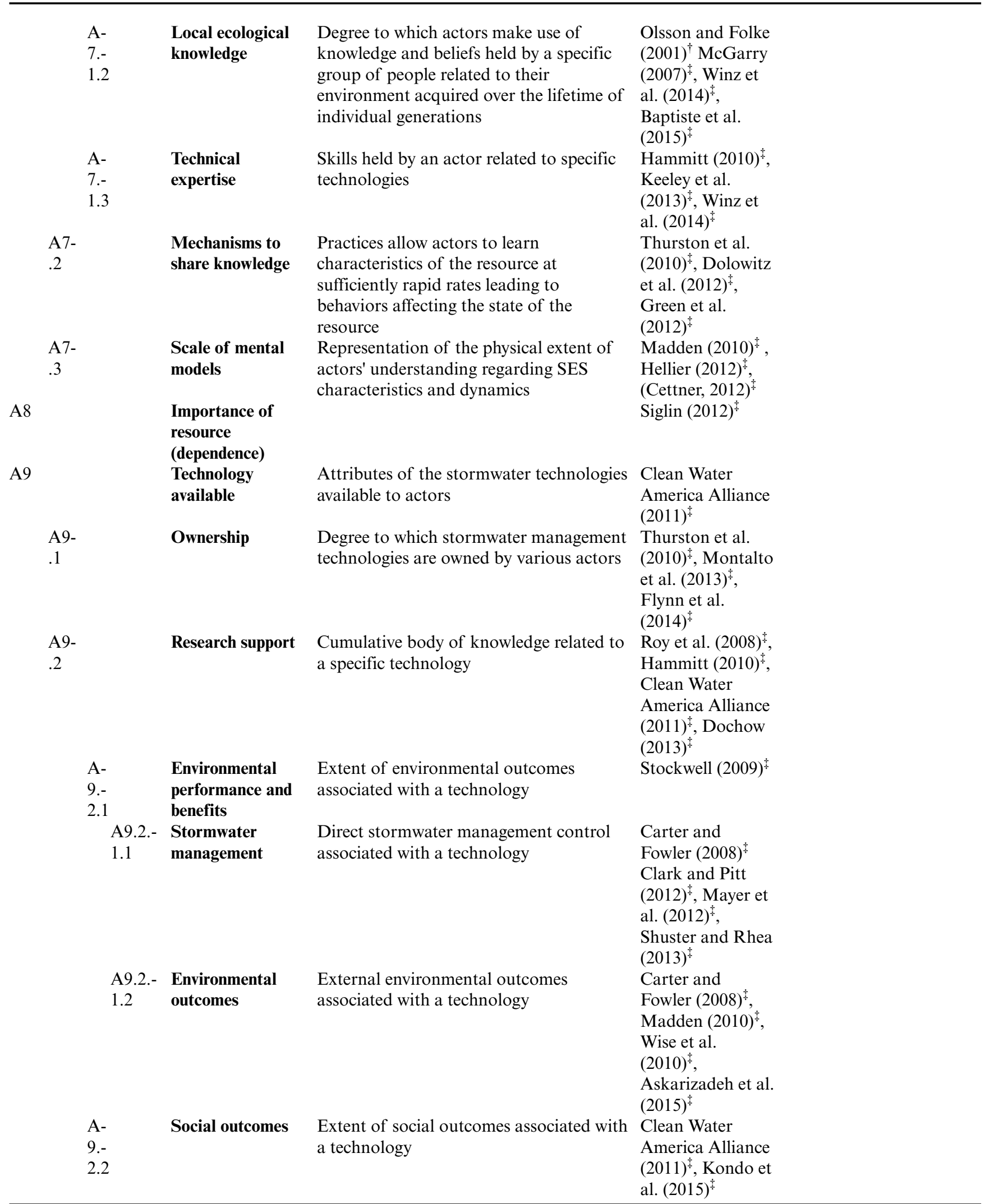




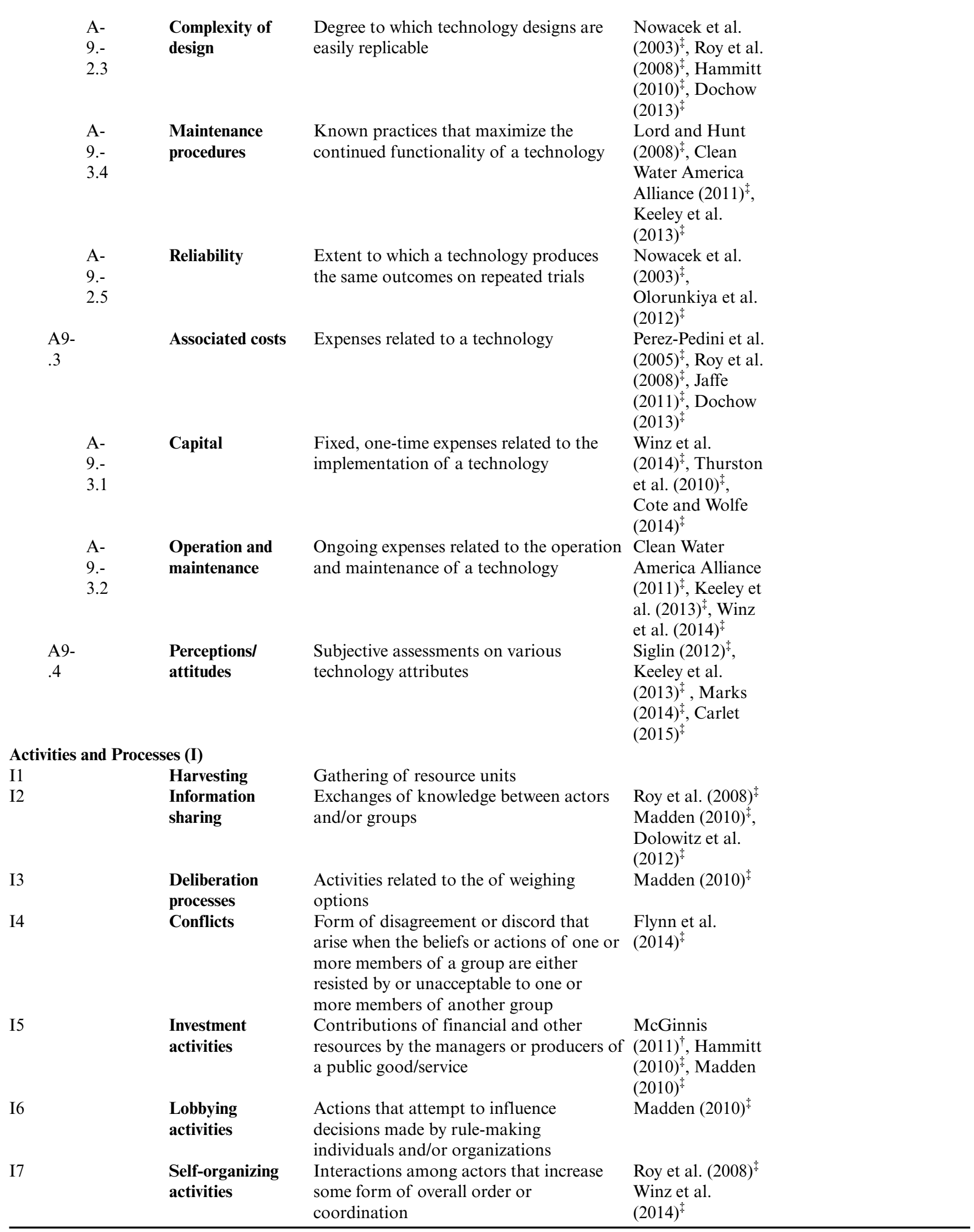


I8

I9

$\mathrm{I} 10$

Evaluative activities

\section{Outcome Criteria (O)}

O1

\section{Social} performance measures

$\mathrm{O} 2$

$\mathrm{O} 3$

Related ecosystems (ECO)

E-

C-

O1

E-

C-

$\mathrm{O} 2$

E-

C-

$\mathrm{O} 3$
Meetings which build social structure between actors, connecting them through various social familiarities Accumulation of new knowledge related to system attributes
Roy et al. (2008)

Hammitt $(2010)^{\ddagger}$

Madden (2010)

Stockwell (2009)

Flynn et al.

$(2014)^{\ddagger}$,

Askarizadeh et al. $(2015)^{\ddagger}$

Determination of which aspects of the McGinnis (2011) observed outcomes are deemed , Madden $(2010)^{\ddagger}$, satisfactory and which aspects are in need Winz et al. of improvement $(2014)^{t}$ Evaluative criteria used to determine McGinnis which aspects of observed outcomes are $\quad(2011)^{\dagger}$, deemed satisfactory and which aspects are (Holloway et al. in need of improvement. Indicators that describe various social conditions

$(2014)^{\ddagger}$

Brown and Farrelly (2008) Madden (2010) Winz et al. $(2014)^{\ddagger}$

Indicators that describe various ecological Burns et al. conditions

$(2012)^{\ddagger}$, Mayer et al. $(2012)^{\ddagger}$ (Roy et al., 2014)

Indicators that describe impacts on other SESs

Tzoulas et al. $(2007)^{\ddagger}$, Foster et al. $(2011)^{\ddagger}$, Mayer et al. $(2012)^{\ddagger}$

$\begin{array}{ll}\text { The broader ecological context within } & \text { McGinnis and } \\ \text { which the focal resource system is located, Ostrom (2014) }\end{array}$ including the determinants of many potential exogenous influences

Recurring characteristics of the statistical Clean Water distribution of weather over an extended America Alliance period of time $(2011)^{\frac{1}{*}}$

Pollution patterns Recurring characteristics of contaminants Lassiter (2007) that cause adverse effects Hammitt (2010)

Nowacek et al. $(2003)^{\ddagger}$, Madden $(2010)^{\ddagger}$, Winz et al. $(2014)^{\ddagger}$

${ }^{\dagger}$ Reference for attribute definition

$\star$ Reference that provides illustration of example of attribute's relationship to green infrastructure adoption in urban stormwater SESs

\section{LITERATURE CITED}

Askarizadeh, A., M.A. Rippy, T.D. Fletcher, D.L. Feldman, J. Peng, P. Bowler, A.S. Mehring, B.K. Winfrey, J.A. Vrugt, A. AghaKouchak, S.C. Jiang, B.F. Sanders, L.A. Levin, S. Taylor, and S.B. Grant. 2015. From Rain Tanks to Catchments: Use of Low-Impact Development to Address Hydrologic Symptoms of the Urban Stream Syndrome. Environmental Science and Technology. 49(19), 11264-11280. doi:10.1021/acs.est.5b01635

Baptiste, A.K. 2014. "Experience is a great teacher": citizens' reception of a proposal for the implementation of green infrastructure as stormwater management technology. Community Development 45(4), 337-352. doi:10.1080/15575330.2014.934255

Baptiste, A.K., C. Foley, and R. Smardon. 2015. Understanding urban neighborhood differences in willingness to implement green infrastructure measures: a case study of Syracuse, NY. Landscape and Urban Planning 136, 1-12. doi:10.1016/j. 
landurbplan.2014.11.012

Basurto, X., S. Gelcich, and E. Ostrom. 2013. The social-ecological system framework as a knowledge classificatory system for benthic small-scale fisheries. Global Environmental Change 23(6): 1366-1380. doi:10.1016/j.gloenvcha.2013.08.001

Berkes, F. 2012. Sacred Ecology, 3rd ed. Routledge, New York, New York, U.S.A.

Brown, R., and M. Farrelly. 2008. Sustainable urban stormwater management in Australia: professional perceptions on institutional drivers and barriers, in: Proceedings of the 11th International Conference on Urban Drainage, Edinburgh, Scotland. Citeseer.

Burns, M.J., T.D. Fletcher, C.J. Walsh, A.R. Ladson, and B.E. Hatt. 2012. Hydrologic shortcomings of conventional urban stormwater management and opportunities for reform. Landscape and Urban Planning 105(3), 230-240.

Carlet, F. 2015. Understanding attitudes toward adoption of green infrastructure: A case study of US municipal officials. Environmental Science \& Policy. 51, 65-76. doi:10.1016/j.envsci.2015.03.007

Carter, T., and L. Fowler. 2008. Establishing Green Roof Infrastructure Through Environmental Policy Instruments. Environmental Management 42(1), 151-164. doi:10.1007/s00267-008-9095-5

Cettner, A. 2012. Overcoming inertia to sustainable stormwater management practice (PhD Thesis). Lulea University of Technology: Lulea, Sweden.

Cettner, A., R. Ashley, A. Hedström, and M. Viklander, M. 2014a. Assessing receptivity for change in urban stormwater management and contexts for action. Journal of Environmental Management 146, 29-41. doi:10.1016/j.jenvman.2014.07.024

Cettner, A., R. Ashley, A. Hedström, and M. Viklander, M. 2014b. Sustainable development and urban stormwater practice. Urban Water Journal 11(3), 185-197. doi:10.1080/1573062X.2013.768683

Clark, S.E., R. Pitt. 2012. Targeting treatment technologies to address specific stormwater pollutants and numeric discharge limits. Water Research. 46(20), 6715-6730. doi:10.1016/j.watres.2012.07.009

Clean Water America Alliance, 2011. Barriers and Gateways to Green Infrastructure. Washington D.C., U.S.A.

Cote, S.A., and S. Wolfe. 2014. Assessing the Social and Economic Barriers to Permeable Surface Utilization for Residential Driveways in Kitchener, Canada. Environmental Practice 16, 6-18. doi:10.1017/S1466046613000641

Debo, T.N., and A. Reese. 2003. Municipal stormwater management, Second Edition. ed. CRC Press, Boca Raton, Florida, U.S.A.

Dietz, M.E., and J.C. Clausen, J.C. Stormwater runoff and export changes with development in a traditional and low impact subdivision. Journal of Environmental Management 87(4), 560-566.

Dochow, D., 2013. Transforming Tradition: A Case Study of Stormwater Management in Clark County, Washington to Assess Barriers to Low Impact Development Strategies (MA Thesis). Evergreen State College. Olympia, Washington, U.S.A. [online] http:// archives.evergreen.edu/masterstheses/Accession86-10MES/Dochow D2013.pdf

Dolowitz, D., M. Keeley, and D. Medearis. 2012. Stormwater management: can we learn from others? Policy Studies. 33(6), 501-521. doi:10.1080/01442872.2012.722289

Dunn, A.D. 2010. Siting green infrastructure: legal and policy solutions to alleviate urban poverty and promote healthy communities. Boston College Environmental Affairs Law Review. 37, 41.

Epstein, G., J.M. Vogt, S.K. Mincey, M. Cox, and B. Fischer. 2013. Missing ecology: integrating ecological perspectives with the social-ecological system framework. International Journal of the Commons 7(2), 432-453.

Fletcher, T.D., C.J. Walsh, D. Bos, V. Nemes, S.R. Rakesh, T. Prosser, B. Hatt, and R. Birch. 2011. Restoration of stormwater retention capacity at the allotment-scale through a novel economic instrument. Water Science \& Technology. 64(2).

Flynn, C.D., C.I. Davidson, and J. Mahoney. 2014. Transformational Changes Associated with Sustainable Stormwater Management Practices in Onondaga County, New York. In ICSI 2014: Creating Infrastructure for a Sustainable World, eds. J. Crittenden, C. Hendrickson, and B. Wallace, November 2014, pp. 89-100. doi: 10.1061/9780784478745.009 
Foster, J., A. Lowe, and S. Winkelman. 2011. The value of green infrastructure for urban climate adaptation. Center for Clean Air Policy, February. Washington, D.C., U.S.A.

Godwin, D., B.L. Parry, F.A. Burris, S.S. Chan, and A. Punton. 2008. Barriers and opportunities for low impact development: case studies from three Oregon Communities. Oregon Sea Grant, Oregon State University Corvallis, Oregon, U.S.A.

Green, O.O., W.D. Shuster, L.K. Rhea, A.S. Garmestani, and H.W. Thurston. 2012. Identification and induction of human, social, and cultural capitals through an experimental approach to stormwater management. Sustainability. 4(8), $1669-1682$.

Hammitt, S.A. 2010. Toward sustainable stormwater management: overcoming barriers to green infrastructure (MS Thesis). Massachusetts Institute of Technology, Cambridge, Massachusetts, U.S.A. [online] URL: http:// http://www.mit.edu/afs.new/athena/ dept/cron/project/urban-sustainability/Stormwater Sarah\%20Madden/Shammitt thesis final.pdf

Hellier, J. 2012. Ecologists and Organizers: Participatory Research for Shared Understanding in the Green Seattle Partnership (MS Thesis). University of Washington. Seattle, Washington, U.S.A. [online] https://dlib.lib.washington.edu/researchworks/ handle/1773/20555

Holloway, C.F., C.H. Strickland Jr, M.B. Gerrard, and D.M. Firger. 2014. Solving the CSO Conundrum: Green Infrastructure and the Unfulfilled Promise of Federal-Municipal Cooperation. Harvard Environmental Law Review. $38,335$.

Jaffe, M.S., M. Zellner, E. Minor, M. Gonzalez-Meler, L. Cotner, D. Massey, H. Ahmed, M. Elberts, H. Sprague, S. Wise, and B. Miller. 2010. Using green infrastructure to manage urban stormwater quality: a review of selected practices and state programs. Illinois Environmental Protection Agency. Springfield, IL, USA.

Jaffe, M. 2011. Environmental Reviews \& Case Studies: Reflections on Green Infrastructure Economics. Environmental Practice 12 (04), 357-365. doi:10.1017/S1466046610000475

Jensen, M.A. 2008. Feasibility of rainwater harvesting for urban water management in Salt Lake City (MS Thesis). The University of Utah. Salt Lake City, Utah, U.S.A. [online] http://content.lib.utah.edu/cdm/ref/collection/etd2/id/1406

Keeley, M., A. Koburger, D.P. Dolowitz, D. Medearis, D. Nickel, and W. Shuster. 2013. Perspectives on the Use of Green Infrastructure for Stormwater Management in Cleveland and Milwaukee. Environmental Management 51(6), 1093-1108. doi:10.1007/ s00267-013-0032-x

Kertesz, R., O.O. Green, and W.D. Shuster. 2014. Modeling the hydrologic and economic efficacy of stormwater utility credit programs for US single family residences. Water Science \& Technology 70(11).

Kingdon, J.W. 1995. Agendas, Alternatives and public policies. Harper Collins. New York, New York, USA.

Kondo, M.C., S.C. Low, J. Henning, and C.C. Branas. 2015. The Impact of Green Stormwater Infrastructure Installation on Surrounding Health and Safety. American Journal of Public Health. 105(3), e114-e121. doi:10.2105/AJPH.2014.302314

Kulkarni, M. 2012. Implementation of green infrastructure as stormwater management in Portland, Oregon (MS Report). Kansas State University. Manhattan, Kansas, U.S.A. [online] https://krex.k-state.edu/dspace/handle/2097/13780

LaBadie, K. 2010. Identifying barriers to low impact development and green infrastructure in the Albuquerque Area (MS Thesis). The University of New Mexico. Albuquerque, New Mexico, U.S.A. [online] www.wrri.nmsu.edu/research/rfp/studentgrants08/reports/ LaBadie.pdf

Lassiter, R. 2007. An Assessment of Impediments to Low-Impact Development in the Virginia Portion of the Chesapeake Bay Watershed (MS Thesis). Virginia Commonwealth University. Richmond, Virginia, U.S.A.[online] http://scholarscompass.vcu.edu/ $\underline{\text { etd } / 892 / \text { ? mode }=\text { full }}$

Lord, W.G., and W.F. Hunt. 2008. Stormwater BMP Maintenance and Certification Program in North Carolina, USA. In Low Impact Development for Urban Ecosystem and Habitat Protection. eds. N. She; and M. Char. American Society of Civil Engineers. pp. 1-6. doi: 10.1061/41009(333)64

Madden, S. A. 2010. Choosing green over gray: Philadelphia's innovative stormwater infrastructure plan. Massachusetts Institute of Technology. Cambridge, Massachusetts, U.S.A. [online] URL: http://www.mit.edu/afs.new/athena/dept/cron/project/urbansustainability/Stormwater Sarah\%20Madden/sarahmadden thesis MIT.pdf 
Marks, A. 2014. Stormwater management in Boston: to what extent are demonstration projects likely to enable citywide use of green infrastructure? Massachusetts Institute of Technology.

Mayer, A.L., W.D. Shuster, JJ. Beaulieu, M.E. Hopton, L.K. Rhea, A.H. Roy, and H.W. Thurston. 2012. Environmental reviews and case studies: Building green infrastructure via citizen participation: A six-year study in the Shepherd Creek (Ohio). Environmental Practice. 14(01), 57-67.

Mbilinyi, B.P., S.D. Tumbo, H.F. Mahoo, E.M. Senkondo, and N. Hatibu. 2005. Indigenous knowledge as decision support tool in rainwater harvesting. Physics and Chemistry of the Earth, Parts A/B/C. 30(11-16), 792-798. doi:10.1016/j.pce.2005.08.022

McGarry, S. 2007. Local Ecological Knowledge of Flooding in the Madison Valley Neighborhood of Seattle, Washington (MA Thesis). Evergreen State College. Olympia, Washington, U.S.A. [online] http://archives.evergreen.edu/masterstheses/Accession86-10MES/ McGarry S\%20MESThesis\%202007.pdf

McGinnis, M.D. 2011. An introduction to IAD and the language of the Ostrom workshop: a simple guide to a complex framework. Policy Studies Journal 39(1), 169-183.

McGinnis, M. D., E. and Ostrom. 2014. Social-ecological framework: initial changes and continuing challenges. Ecology and Society 19(2): 30. http://dx.doi.org/10.5751/ES-06387-190230

Montalto, F.A., T.A. Bartrand, A.M. Waldman, K.A. Travaline, C.H. Loomis, C. McAfee, J.M. Geldi, G.J. Riggall, and L.M. Boles. 2013. Decentralised green infrastructure: the importance of stakeholder behaviour in determining spatial and temporal outcomes.

Structure and Infrastructure Engineering 9(12), 1187-1205.

Nowacek, D., E. Nelson, and J. Petchenik. 2003. Social and Institutional Barriers to Stormwater Infiltration. Wisconsin Department of Natural Resources-Bureau of Integrated Science Services. Madison, Wisconsin, U.S.A. [online] www.kitsaplid.org/resources/ Barriers to SW Infiltration.pdf

Olorunkiya, J., E. Fassman, and S. Wilkinson. 2012. Risk: A fundamental barrier to the implementation of low impact design infrastructure for urban stormwater control. Journal of Sustainable Development. 5(9), 27.

Olsson, P., and C. Folke. 2001. Local ecological knowledge and institutional dynamics for ecosystem management: A study of Lake Racken watershed, Sweden. Ecosystems. 4(2), 85-104.

Ostrom, E., 2007. A diagnostic approach for going beyond panaceas. Proceedings of the National Academy of Sciences 104(39), 15181-15187. doi:10.1073/pnas.0702288104

Ostrom, E., R. Gardner, and J. Walker. 1994. Rules, Games, and Common-pool Resources. University of Michigan Press. Ann Arbor, Michigan, U.S.A.

Parikh, P., M.A. Taylor, T. Hoagland, H. Thurston, and W. Shuster. 2005. Application of market mechanisms and incentives to reduce stormwater runoff: An integrated hydrologic, economic and legal approach. Environmental Science \& Policy. 8(2), $133-144$.

Perez-Pedini, C., J.F. Limbrunner, and R.M. Vogel. 2005. Optimal location of infiltration-based best management practices for storm water management. Journal of Water Resources Planning and Management 131(6), 441-448.

Perreault, T., S. Wraight, and M. Perreault. 2012. Environmental injustice in the Onondaga lake waterscape, New York State, USA. Water Alternatives 5(2), 485-506.

Rhea, L., W. Shuster, J. Shaffer, and R. Losco. 2014. Data proxies for assessment of urban soil suitability to support green infrastructure. Journal of Soil and Water Conservation. 69(3), 254-265.

Roy, A.H., L.K. Rhea, A.L. Mayer, W.D. Shuster, J.J. Beaulieu, M.E. Hopton, M.A. Morrison, and A.S. Amand. 2014. How Much Is Enough? Minimal Responses of Water Quality and Stream Biota to Partial Retrofit Stormwater Management in a Suburban Neighborhood. PLoS One 9(1), e85011. doi:http://dx.doi.org.libezproxy2.syr.edu/10.1371/journal.pone.0085011

Roy, A.H., and W.D. Shuster. 2009. Assessing impervious surface connectivity and applications for watershed management. Journal of the American Water Resources Association. 45(1), 198-209.

Roy, A.H., S.J. Wenger, T.D. Fletcher, C.J. Walsh, A.R. Ladson, W.D. Shuster, H.W. Thurston, and R.R. Brown. 2008. Impediments and solutions to sustainable, watershed-scale urban stormwater management: lessons from Australia and the United States. 
Environmental management. 42(2), 344-359.

Salkin, P.E. 2009. Sustainability and Land Use Planning: Greening State and Local Land Use Plans and Regulations to Address Climate Change Challenges and Preserve Resources for Future Generations. William and Mary Environmental Law and Policy Review. 34, 121.

Shandas, V., and W. B. Messer. 2008. Fostering Green Communities Through Civic Engagement: Community-Based Environmental Stewardship in the Portland Area. Journal of the American Planning Association. 74(4), 408-418. doi:10.1080/01944360802291265

Shuster, W., and L. Rhea. 2013. Catchment-scale hydrologic implications of parcel-level stormwater management (Ohio USA). Journal of hydrology. 485, 177-187.

Shuster, W.D., S. Dadio, P. Drohan, R. Losco, and J. Shaffer. 2014. Residential demolition and its impact on vacant lot hydrology: Implications for the management of stormwater and sewer system overflows. Landscape and Urban Planning. 125, 48-56.

Shuster, W.D., A.S. Garmestani, O.O.Green, L.K. Rhea, A.H. Roy, and H.W. Thurston. 2013. Catchment-scale stormwater management via economic incentives-an overview and lessons-learned, in: Proceedings of the 8th International Conference of NOVATECH. GRAIE, Lyon, France.

Shuster, W.D., M.A. Morrison, and R. Webb. 2008. Front-loading urban stormwater management for success - A perspective incorporating current studies on the implementation of retrofit low-impact development. Cities and the Environment.1(2), 8.

Siglin, D.D. 2012. Municipal Use of Green Stormwater Infrastructure in The Delaware River Basin: Barriers, Drivers, And Opportunities for Implementation (MS Thesis). The Pennsylvania State University. State College, Pennsylvania, U.S.A. [online] https://etda.libraries.psu.edu/paper/15290/12231

Singh, C. 2006. The process of and barriers to environmentally-oriented real estate development: examining the role of organizational structure, project delivery methods and contracts in low impact development (MS Thesis). Massachusetts Institute of Technology. Cambridge, Massachusetts, U.S.A. [online] http://dspace.mit.edu/handle/1721.1/37465

Stockwell, A. 2009. Analysis of Barriers to Low Impact Development in the North Coast Redwood Region, California (MS Thesis). Humboldt State University. Arcata, California, U.S.A. [online] http://humboldt-dspace.calstate.edu/handle/2148/595

Thurston, H.W., H.C. Goddard, D. Szlag, and B. Lemberg. 2003. Controlling storm-water runoff with tradable allowances for impervious surfaces. Journal of Water Resources Planning and Management 129(5), 409-418.

Thurston, H.W., M.A. Taylor, W.D. Shuster, A.H. Roy, and M.A. Morrison. 2010. Using a reverse auction to promote household level stormwater control. Environmental Science \& Policy. 13(5), 405-414.

Travaline, K., F. Montalto, and C. Hunold. 2015. Deliberative Policy Analysis and Policy-making in Urban Stormwater Management. Journal of Environmental Policy \& Planning. 17(5), 691-708. doi:10.1080/1523908X.2015.1026593

Tzoulas, K., K. Korpela, S. Venn, V. Yli-Pelkonen, A. Kaźmierczak, J. Niemela, and P. James. 2007. Promoting ecosystem and human health in urban areas using green infrastructure: a literature review. Landscape and Urban Planning. 81(3), 167-178.

Winz, I., S. Trowsdale, and G. Brierley. 2014. Understanding barrier interactions to support the implementation of sustainable urban water management. Urban Water Journal 11(6), 497-505.

Wise, S., J. Braden, D. Ghalayini, J. Grant, C. Kloss, E. MacMullan, S. Morse, F. Montalto, D. Nees, D. Nowak, S. Peck, S. Shaikh, and C. Yu. 2010. Integrating Valuation Methods to Recognize Green Infrastructure's Multiple Benefits, in: Low Impact Development 2010: Redefining Water in the City. Eds. S. Struck, and K. Lichten. American Society of Civil Engineers, pp. 1123-1143. doi: $10.1061 / 41099(367) 98$

Wolch, J.R., J. Byrne, and J.P Newell. 2014. Urban green space, public health, and environmental justice: The challenge of making cities "just green enough." Landscape and Urban Planning. 125, 234-244. doi:10.1016/j.landurbplan.2014.01.017 